\title{
Acerola: importance, culture conditions, production and biochemical aspects
}

\author{
Sandra Aparecida de Assis ${ }^{1,2}$, Fernandes Pedro Fernandes ${ }^{2}$, Antônio Baldo Geraldo MARTins ${ }^{3}$,
} Olga Maria Mascarenhas de FARIA OLIVEIRA ${ }^{1 *}$

${ }^{1}$ Instituto de Química, Departamento de Bioquímica e Tecnologia Química, UNESP, Rua Prof. Francisco Degni, $\mathrm{s} / \mathrm{n}$. CP 355, CEP 14801-970, Araraquara, SP, Brazil olgaenzimologia@yahoo.com.br

2 Departamento de Saúde, Universidade Estadual de Feira de Santana, UEFS, $\mathrm{Br} 116$, km 03, Campus Universitário, Feira de Santana, CEP 44031 460, BA, Brazil

sandraassis@uefs.br

${ }^{3}$ Departamento of Horticultura, Faculdade de Ciências Agrárias e Veterinárias de Jaboticabal, UNESP, Jaboticabal, Brazil

${ }^{4}$ Institute for Biotechnology and Bioengineering (IBB), Centre for Biological and Chemical Engineering, Superior Technical Institute, Av. Rovisco Pais, P-1049-001 Lisboa, Portugal

pedro.fernandes@mail.ist.utl.pt

* Correspondence and reprints

Received 17 June 2007 Accepted 11 October 2007

Fruits, 2008, vol. 63, p. 93-101 (C) 2008 Cirad/EDP Sciences All rights reserved DOI: $10.1051 /$ fruits:2007051 www.fruits-journal.org RESUMEN EsPañol, p. 101

\section{Acerola: importance, culture conditions, production and biochemical} aspects.

Abstract - Origin and importance. Acerola, or Malpighia emarginata D.C., is native to the Caribbean islands, Central America and the Amazonian region. More recently, it has been introduced in subtropical areas (Asia, India and South America). The vitamin C produced by acerola is better absorbed by the human organism than synthetic ascorbic acid. Exportation of acerola crops is a potential alternative source of income in agricultural businesses. In Brazil, the commercial farming of acerola is quite recent. Climatic conditions. Acerola is a rustic plant. It can resist temperatures close to $0{ }^{\circ} \mathrm{C}$, but it is well adapted to temperatures around $26{ }^{\circ} \mathrm{C}$ with rainfall between $(1200$ and 1600$) \mathrm{mm}$ per year. Fruit characteristics. Acerola fruit is drupaceous, whose form can vary from round to conic. When ripe, it can be red, purple or yellow. The fruit weight varies between ( 3 and 16) g. Maturation. Acerola fruit presents fast metabolic activity and its maturation occurs rapidly. When commercialised in ambient conditions, it requires fast transportation or the use of refrigerated containers to retard its respiration and metabolism partially. Production and productivity. Flowering and fruiting are typically in cycles associated with rain. Usually, they take place in 25 -day cycles, up to 8 times per year. The plant can be propagated by cuttings, grafting or seedlings. Harvest. Fruits produced for markets needs to be harvested at its optimal maturation stage. For distant markets, they need to be packed in boxes and piled up in low layers; transportation should be done in refrigerated trucks in relatively high humid conditions. Biochemical constituents. Acerola is the most important natural source of vitamin C $[(1000$ to 4500) $\mathrm{mg} \cdot 100^{-1} \mathrm{~g}$ of pulp], but it is also rich in pectin and pectolytic enzymes, carotenoids, plant fibre, vitamin $\mathrm{B}$, thiamin, riboflavin, niacin, proteins and mineral salts. It has also shown active anti-fungal properties. Products and market. Acerola is used in the production of juice, soft drinks, gums and liqueurs. The USA and Europe are great potential markets. In Europe, acerola extracts are used to enrich pear or apple juices. In the USA, they are used in the pharmaceutical industry. Conclusions. The demand for acerola has increased significantly in recent years because of the relevance of vitamin $C$ in human health, coupled with the use of ascorbic acid as an antioxidant in food and feed. Acerola fruit contains other significant components, which are likely to lead to a further increase in its production and trade all over the world.

Brazil / Malpighia emarginata / fruits / proximate composition / uses / world markets

\section{Acérola : importance, conditions de culture, production et aspects biochimiques.}

Résumé - Origine et importance. L'acérola, ou Malpighia emarginata D.C., est originaire des îles Caraïbes, d'Amérique centrale et d'Amazonie. Cette plante a été introduite récemment en zones subtropicales (Asie, Inde, Amérique du Sud). La vitamine C produite par l'acérola est mieux absorbée par l'organisme humain que l'acide ascorbique synthétique. L'exportation des fruits d'acérola est une source de revenus potentiels pour les exploitations agricoles. Au Brésil, la culture industrielle de cette plante est tout à fait récente. Conditions climatiques. L'acérola est une plante rustique qui peut résister aux températures avoisinant $0{ }^{\circ} \mathrm{C}$, mais qui est bien adaptée aux températures proches de $26{ }^{\circ} \mathrm{C}$ et avec des précipitations entre $(1200$ et 1600) $\mathrm{mm}$ par an. Caractéristiques de fruit. Le fruit de M. emarginata est une drupe dont la forme peut être de ronde à conique. Mûr, il peut être rouge, pourpre ou jaune. Son poids varie de (3 et 16) g. Maturation Le métabolisme de l'acérola est rapide de même que sa maturation. Si ce fruit est commercialisé en conditions ambiantes, son transport doit être rapide, ou bien il faut utiliser des containers frigorifiés pour retarder partiellement sa respiration et son métabolisme. Production et productivité. La floraison et la production interviennent typiquement par cycles liés à la pluie. Habituellement, ces évènements se réalisent en cycles de 25 jours, jusqu'à huit fois par an. La plante peut être propagée par boutures, greffes ou semis. Récolte. Les fruits écoulés sur les marchés doivent être récoltés à leur maturation optimale. Pour des mises en marché éloigné, ils doivent être conditionnés en caisses empilées sur de faibles hauteurs ; le transport devrait être fait en camions frigorifiés et en conditions humides relativement élevées. Constituants biochimiques. Le

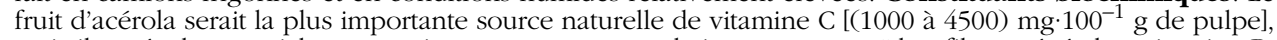
mais il est également riche en pectine et enzymes pectolytiques, carotenoïdes, fibres végétales, vitamine B, thiamine, riboflavine, niacine, protéines et sels minéraux. Il possède également des propriétés antifongiques actives. Produits et marché. L'acérola est employé dans la production de jus, boissons non alcoolisées, gommes et liqueurs. Les États-Unis et l'Europe sont de grands marchés potentiels. En Europe, les extraits d'acérola servent à enrichir des jus de poires ou de pommes. Aux États-Unis, ils sont utilisés en industries pharmaceutiques. Conclusions. La demande d'acérola a bien augmenté au cours de ces dernières années en raison de l'intérêt de la vitamine $\mathrm{C}$ pour la santé humaine, ajouté à l'utilisation de l'acide ascorbique comme antioxydant en alimentation et nutrition. Le fruit d'acérola contient d'autres constituants intéressants, susceptibles de conduire à un accroissement ultérieur de sa production et à son commerce dans le monde entier.

Brésil / Malpighia emarginata / fruits / composition globale / utilisation / marché mondial 


\section{Origin and importance}

Fruits are important sources of nutrients in the human diet. They have high contents of carbohydrates (glucose, fructose, other soluble sugars and pectin), vitamins, minerals and organic acids, although they are usually very low in proteins and fats [1]. Compositional, nutritional and functional properties are essential parameters for defining food quality [2]. Several studies have consistently evidenced that a diet rich in fruits and vegetables reduces the risk of chronic diseases and cancer and therefore leads to reduced morbidity and mortality [3].

Among fruits useful in the human diet, there is acerola, which is produced by a small tree.

Acerola belongs to the genus Malpighia, which comprises 30 species of shrubs and small trees native to the American tropics and subtropics [4]. This small tree bears a 3stoned, red, drupaceous fruit known by the common names Barbados cherry or West Indian cherry in the English-speaking Caribbean, although the name acerola, of Puerto Rican origin, has been gaining widespread acceptance [4]. In the past, the plant was known by the synonyms Malpighia glabra L. and Malpighia punicifolia L., but recent taxonomic work has resulted in the acceptance of Malpighia emarginata D.C. as its current scientific name [4].

Acerola can be found from South Texas, through Mexico and Central America to northern South America and throughout the Caribbean [5]. More recently, it has been introduced in subtropical areas throughout the world (Asia, India and South America); nevertheless, some of the largest plantations are in Brazil [5, 6], particularly in the Northern region of this country. Currently, Brazil is the greatest world producer of acerola. The fruit can be used to prepare different products: ice cream, gelatin, juice (integral, concentrated, lyophilised), soft drinks, nectar, jelly, gum, fruit conserve, nutraceutics, yogurts and sodas [7].

Acerola competes in the market sector of consumers that prefer natural products. When compared with synthetic ascorbic acid, the vitamin $\mathrm{C}$ produced by this fruit is better absorbed by the human organism. We can only absorb $50 \%$ of synthetic vitamin intake in opposition to that of natural vitamins. In addition, it is a differential area with a variety of products [8].

Due to the existence of a great market for derivates of fresh fruits in the Northern hemisphere, exportation of acerola crops is a potential alternative source of income in agricultural businesses [9].

Acerola farming for exportation requires a lot of workforce, mainly in the steps of harvesting and classification of the fruit, thus occupying an important position among the fruits commercially exploited. Because acerola crops are perennial and have production all year long when cultivated in irrigated fields, it not only requires a lot of workforce but it also provides small farms with continuous income all year round [10].

For over 50 years, acerola has been known in Brazil. However, its commercial farming is quite recent and was implanted without technological knowledge, resulting in plantations with a great variety of cultivars [10].

\section{Climatic conditions}

Acerola is a rustic plant that can be produced in tropical and subtropical climates at the same time because it can resist temperatures close to $0{ }^{\circ} \mathrm{C}[11]$.

It is well adapted to temperatures around $26{ }^{\circ} \mathrm{C}$ [11]. Moreover, it grows and produces well when rainfall is between (1200 and 1600) $\mathrm{mm}$ per year. In areas with little rainfall, the acerola fields need irrigation.

Acerola does not present any specific soil demand, its farming being possible in sandy soils as well as in clayey ones. Average fertile soils composed of a mixture of both clay and sand seem to be optimal for its farming since they hold more humidity [11].

\section{Characteristics of the fruit}

Acerola fruit is drupaceous, whose form can vary from round to conic. When ripe, it can 
Table I.

Relationship of the mean values \pm standard deviations of ascorbic acid content, pectin content, total protein content and pectinmethylesterase (PME) specific activity in different stages of acerola development, varying from immature (stage 1) up to ripe mature (stage 5) (Brazil).

\begin{tabular}{lcccc}
$\begin{array}{l}\text { Stage of } \\
\text { fruit development }\end{array}$ & $\begin{array}{c}\text { Ascorbic acid } \\
\left(\mathrm{mg} \cdot 100 \mathrm{~g}^{-1} \text { of fresh pulp) }\right.\end{array}$ & $\begin{array}{c}\text { Pectin } \\
(\%)\end{array}$ & $\begin{array}{c}\text { Protein } \\
\left(\mathrm{mg} \cdot 100 \mathrm{~mL}^{-1} \text { of juice }\right)\end{array}$ & $\begin{array}{c}\text { PME specific activity } \\
\text { units } \cdot \mathrm{g}^{-1} \text { of pulp }\end{array}$ \\
\hline 1 & $2424.24 \pm 0.0 \mathrm{a}$ & $4.51 \pm 0.10 \mathrm{a}$ & $2.15 \pm 0.0 \mathrm{a}$ & $0.61 \pm 0.01 \mathrm{~d}$ \\
2 & $1813.73 \pm 0.09 \mathrm{~b}$ & $3.63 \pm 0.03 \mathrm{~b}$ & $2.03 \pm 0.0 \mathrm{a}$ & $2.08 \pm 0.01 \mathrm{a}$ \\
3 & $1457.78 \pm 0.0 \mathrm{c}$ & $3.00 \pm 0.03 \mathrm{c}$ & $2.13 \pm 0.0 \mathrm{a}$ & $1.22 \pm 0.01 \mathrm{~b}$ \\
4 & $1454.3 \pm 0.0 \mathrm{~d}$ & $2.67 \pm 0.03 \mathrm{~d}$ & $2.31 \pm 0.0 \mathrm{~b}$ & $0.79 \pm 0.03 \mathrm{c}$ \\
5 & $957.24 \pm 0.0 \mathrm{e}$ & $2.99 \pm 0.03 \mathrm{c}$ & $3.20 \pm 0.0 \mathrm{c}$ & $0.55 \pm 0.0 \mathrm{~d}$ \\
\hline
\end{tabular}

be red, purple or yellow. Colour is a very important characteristic since the processing industry prefers red fruits, discarding purple or yellow ones. The fruits grow isolated or in clusters with two or more fruits, always in the axis of a leaf [11]

The fruit weight varies between ( 3 and 16) $\mathrm{g}$ according to the potential of plants and the conditions of the farming. In general, fruits that are grown isolated are bigger than fruits in clusters [11].

\section{Aspects of maturation}

Acerola fruit presents fast metabolic activity and its maturation occurs rapidly; there is no need to use any activator to get the acerola ready to consume. On the other hand, when commercialised in ambient conditions, it requires fast transportation or the use of refrigerated containers to retard its respiration and metabolism partially [9]. This feature may make the trade of acerola to distant areas difficult.

After the cropping, metabolic reactions continue in the fruit and the physiological process is maintained for a considerable time. In acerola, as well as in other tropical fruits, a series of alterations occurs during the process of maturation, ripening and senescence [9], the main ones being the degradation of chlorophyll, the presence of car- otenoids, decrease in acidity, increase in reductor sugars and, mainly, the acute decrease in ascorbic acid during these stages (table I).

\section{Production and productivity}

There are significant differences among cultivated areas, mainly depending on the variety of plants or the clone used, and on the conditions of farming. The genetic potential of the plants along with the edaphoclimatic conditions are likely to strongly influence the production and productivity of the acerola tree. Flowering and concomitant fruiting can occur throughout the year, but they are typically in cycles associated with rain. Usually, they take place in 25-day cycles, up to 8 times per year [12]. Plants grown in dry areas (annual rainfall around $1480 \mathrm{~mm}$ ) in irrigated fields presented production between (2.01 and 27.11) kg per tree in four crops a year [9]. Besides, plants that produce a high content of ascorbic acid are to be selected [9]. The plant can be propagated by cuttings, grafting or seedlings, the former approach being currently favoured $[10,13]$. However, high variability in fruit quality is observed in Brazilian acerola crops, especially those propagated by seeds [14]. In-vitro cultivation of acerola through micropropagation has been recently reported, with encouraging results [15]. 


\section{Harvesting factors}

When the time comes to do the fruit harvest, there is a great concern about the correct time, frequency, procedures and forms of storage. Acerola fruit has the maturation process divided into different stages, varying from immature up to ripe mature. Fruit produced for markets needs to be cropped at its optimal maturation stage. Due to the fragility of the fruits, this process is delicate and makes up most of the cost in farming of acerola. It is necessary to avoid injuring fruit, which can accelerate its deterioration [10].

Fruit need to be cropped two or three times a week or daily, according to the productivity of the plant, in order to prevent the fruits from falling on the ground [10].

When mature fruits are to be sold in distant markets, they need to be packed in boxes and piled up in low layers, because the weight of high layers can cause injuries to the fruits in lower layers. Whenever possible, transportation should be done in refrigerated trucks in relatively high humid conditions [10].

\section{Biochemical constituents}

Acerola has been considered one of the most important natural sources of vitamin C [2] of which the level is typically within (1000 to 4500) $\mathrm{mg} \cdot 100^{-1} \mathrm{~g}$ of pulp [16]. In addition to vitamin $\mathrm{C}$, acerola is also rich in pectin and pectolytic enzymes, carotenoids, plant fibre, a small amount of vitamin B and several biofunctional substances [17], thiamin, riboflavin, niacin, proteins and mineral salts, mainly iron, calcium and phosphorus $[6,18]$ (table II). Acerola has also shown active anti-fungal properties [20]. Its high antioxidant content has contributed to the use of acerola extracts in the prevention of age-related diseases, such as hypertension and cancer [21].

\subsection{Ascorbic acid}

Since acerola has high vitamin C (ascorbic acid) content (table I), it may also be used for the production of vitamin $\mathrm{C}$ concentrate for pharmaceutical purposes or enrichment of industrialised foods [22].

Table II.

Content of acerola fruit (per $100 \mathrm{~g}$ ), according to Freitas et al. [19].

(a) Proximate composition

$\begin{array}{lcccccccc}\text { Acerola } & \begin{array}{c}\text { Energy } \\ (\mathrm{kcal})\end{array} & \text { Water } & \text { Protein } & \text { Total lipid (fat) } & \text { Ash } & \text { Carbohydrate } & \text { Total dietary fibre } & \text { Total sugars } \\ & & & & & \left(\mathrm{g} \cdot 100 \mathrm{~g}^{-1}\right) & \\ \text { Fruit } & 32 & 91.41 & 0.40 & 0.30 & 0.20 & 7.69 & 1.1 & - \\ \text { Juice } & 23 & 94.30 & 0.40 & 0.30 & 0.20 & 4.80 & 0.3 & 4.50\end{array}$

(b) Minerals

\begin{tabular}{|c|c|c|c|c|c|c|c|c|c|}
\hline \multirow[t]{2}{*}{ Acerola } & Calcium & Iron & Magnesium & Phosphorus & Potassium & Sodium & Zinc & Copper & \multirow{2}{*}{$\begin{array}{l}\text { Selenium } \\
\left(\mu \mathrm{g} \cdot 100 \mathrm{~g}^{-1}\right)\end{array}$} \\
\hline & \multicolumn{8}{|c|}{$\left(\mathrm{mg} \cdot 100 \mathrm{~g}^{-1}\right)$} & \\
\hline Fruit & 12 & 0.20 & 18 & 11 & 146 & 7 & 0.1 & 0.086 & 0.6 \\
\hline Juice & 10 & 0.50 & 12 & 9 & 97 & 3 & 0.10 & 0.086 & 0.1 \\
\hline
\end{tabular}

(c) Vitamins

\begin{tabular}{|c|c|c|c|c|c|c|c|}
\hline \multirow[t]{2}{*}{ Acerola } & Thiamin & Riboflavin & Niacin & Pantothenic acid & Vitamin B-6 & Folate food & Vitamin A \\
\hline & \multicolumn{5}{|c|}{$\left(\mathrm{mg} \cdot 100 \mathrm{~g}^{-1}\right)$} & \multicolumn{2}{|c|}{$\left(\mu \mathrm{g} \cdot 100 \mathrm{~g}^{-1}\right)$} \\
\hline Fruit & 0.020 & 0.060 & 0.400 & 0.309 & 0.009 & 14 & 767 \\
\hline Juice & 0.020 & 0.060 & 0.400 & 0.205 & 0.004 & 14 & 509 \\
\hline
\end{tabular}


Ascorbic acid is present in plant tissues undergoing active growth and development, and its amount varies among species and cultivars. It is most sensitive to destruction when it is subjected to adverse handling by extended storage, high temperatures, low relative humidity, physical damage and chilling injury. Ascorbic acid is easily oxidised, particularly in aqueous solutions, and greatly favoured by the presence of oxygen heavy metal ions, especially $\mathrm{Cu}^{2+}, \mathrm{Ag}^{+}$and $\mathrm{Fe}^{3+}$, and by alkaline $\mathrm{pH}$ and high temperature [23].

Ascorbic acid plays a key role in the biosynthesis of collagen, carnitine, neurotransmitters, corticoids and catecholamines. It plays a role in the synthesis and maintenance of tissues as well as in the formation of bones, teeth muscles and skin [8, 24].

\subsection{Pectin substances}

Pectin substances are present in practically all fruits and vegetables [25]. Pectin substances are responsible for the consistency, turbidity and appearance of fruit juices [26]. In fact, the presence of pectin substances in fruit juices causes a considerable increase in their viscosity, thereby impeding the process of filtration and subsequent concentration [26, 27].

In fruits, the pectin substances account for about $0.5-4 \%$ of fresh material weight. When the tissue is ground, the pectin is found in the liquid phase (soluble pectin) causing an increase in viscosity and the formation of pulp particles, whereas other pectin molecules remain bound to cellulose and thus facilitate water retention [28].

Pectin is involved in the mechanism of the fruit maturation. In an unripe fruit, pectin is bound to cellulose microfibrils in the cell walls. Such pectin is insoluble and hence confers rigidity on cell walls. However, during ripening the structure of pectin is altered by natural enzymes present in the fruits [28].

\subsection{Pectinmethylesterase enzyme (PME)}

Various enzymes are responsible for the depolymerisation of pectin substances, act- ing on the main galacturonate backbone; particularly, endopolygalacturonase (EC: 3.2.1.15) acts on pectin and polygalcturonase acid, respectively [29]. The enzyme pectinmethylesterase (PME, EC: 3.1.1.11) has been found in plants as well as in pathogenic fungi and bacteria [30] and catalyses the hydrolysis of the methyl ester groups from pectin; after this, the pectin can be hydrolysed by polygalacturonase action. Plant PME is used in the preparation of low methoxyl pectin and in the destabilisation of cloud in fruit juices [29, 31]. Scientists have begun to use a greater range of enzymes more efficiently [28]. As a result, pectinases are today one of the upcoming enzymes of the commercial sector.

PME has been related to fruit senescence [32] and to primary cell wall growth [33]. Fruit softening has been generally related to the degradation of the pectin middle lamella region of the cell wall by pectinmethylesterase and polygalacturonase [32].

Recently, a PME from acerola was characterised after partial purification by filtration in Sephadex G-100. The extract recovered showed different PME isoforms, with high thermal stability [34]. Acerola PME displayed high catalytic activity at relatively high temperatures [34, 35], which may induce changes in juice flavour. This may compromise the use of PME for juice clarification. Therefore, alternative technological approaches must be worked out to solve the problem of juice clarification in acerola.

\subsection{Antioxidant constituents of acerola}

Fruits and vegetables contain different antioxidant compounds, such as vitamin C, vitamin $\mathrm{E}$ and carotenoids, whose activities have been established in recent years. However, these compounds are not the only ones contributing to the antioxidant activity of fruit and vegetables. Recent work showed that the presence of polyphenol compounds, such as flavonoids, in fruits and vegetables also contributes to the beneficial effects of this group of foods [36-38]; apart from their biological properties, flavonoids are also of interest in the food, cosmetic and 
pharmaceutical industries, since they can be used as substitutes for synthetic antioxidants [39].

Few reports have been published about phytochemical contents and chemical changes during the maturation of acerola [2]. In studies of this fruit, different kinds of genotypes presented high phenolic and carotenoid contents [2].

\subsection{Additional studies of acerola chemical composition}

Although acerola has proven to be useful for improving the quality of fruit products or for producing pharmacological and nutritional products, only a few studies have been focused on this fruit [16]. Fitting and Miller [40] studied stability of ascorbic acid and bottled acerola juice alone and combined with other fruit juices. Cavalcante and Amaya [41] studied the carotenoid composition of the acerola fruit, while Cruz et al. [42] studied the variations in the content of ascorbic acid in the acerola as a function of the fruit maturation stage and storage temperature. Chan and Yamamoto [43] determined the kinetics of anthocyanin decomposition in acerola juice. Caceres [20] evaluated its antifungal activity for the treatment of dermatophytic infections and Ciolino [44] worked on the compounds responsible for added caramel colour in adulterated acerola juice.

The effect of the fruit maturity stage on the chemical composition (colour vitamin $\mathrm{C}$, soluble solids, protein, ash, moisture, titrable acidity, $\mathrm{pH}$ and sugars) and volatile components of acerola were determined in three different stages by Vendramini and Trugo [45]. Carrington and King [4] examined the growth and development and characterised its postharvest respiratory behaviour.

\section{Products and market}

For commercial applications, the use of natural ascorbic acid in infant formulas has been suggested as a way to complement, enrich and conserve them. It is important to note the importance of vitamin $\mathrm{C}$ as an antioxidant, in the preservation of dry and frozen fruits. If used along with citric acid, it is effective in the prevention of the oxidation process that occurs during the dehydration and freezing of many fruits such as papayas, pears, apples, passion fruits and pineapples [8].

In Japan, acerola is used in the production of juice, soft drinks, gums and liqueurs. The USA and Europe are great potential markets due to the scarcity of similar products. In Europe, mainly in Germany, France, Belgium and Hungary, acerola extracts are used to enrich pear or apple juices. In the USA, its main use has been in the pharmaceutical industry. Latin America is also a promising market, mainly in countries such as Argentina, Chile and Uruguay [46].

\section{Conclusions}

The demand for acerola has increased significantly in recent years because of the relevance of vitamin $\mathrm{C}$ in human health, coupled with the use of ascorbic acid as an antioxidant in food and feed, namely in juices. Acerola fruit has additionally been shown to also contain other significant components, which are likely to lead to a further increase in its production and trade all over the world. The need for careful planning in order to avoid deterioration of biofunctional activity has been highlighted. In particular, it has been shown during the immature green and green stages. Acerola can be a potential useful source for pectin, a macromolecule currently used in the candy industry and in the enrichment of food as dietary fibre.

\section{Acknowledgements}

The authors thank FAPESP, CAPES and PROPP-UNESP who financed this work. P. Fernandes acknowledges grant SFRH/ BPD/20416/2004 from the Fundação para a Ciência e a Tecnologia, Portugal. 


\section{References}

[1] Araújo C.L., Ingrid W.L., Bezerra W.L., Dantasa I.C., Lima T.V.S., Oliveira A.S.O, Mirandab M.R., Leite E.L., Salesa M.P., Biological activity of proteins from pulps of tropical fruits, Food Chem. 85 (2004) 107-110.

[2] Lima L.A.G., Melo E.A.S., Maciel M.S.I, Prazeres FG., Rosimar S., Musser B., Lima D.A.E.S., Total phenolic and carotenoid contents in acerola genotypes harvested at three ripening stages, Food Chem. 90 (2005) 565-568.

[3] Lindsay D.G., Astley S.B., European research on the functional effects of dietary antioxidants - EUROFEDA, Mol. Asp. Med. 23 (2002) 1-38.

[4] Carrington C.M.S., King R.A.G., Fruit development and ripening in Barbados cherry, Malpighia emarginata D.C., Sci. Hortic. 92 (2002) 1-7.

[5] Assis S.A., Lima D.C., Faria Oliveira O.M.M., Activity of pectinmethylesterase, pectin content and vitamin $\mathrm{C}$ in acerola fruit at various stages of fruit development, Food Chem. 74 (2001) 133-137.

[6] Facciola S., Cornucopia: a source book of edible plants, Kampong Publ., California USA, 1990, $127 \mathrm{p}$.

[7] Mezadri T., Fernández-Pachón M.S., Villaño D., García-Parrilla M.C., Troncoso, A.M., El fruto de la acerola: composición y posibles usos alimenticios, Arch. Latinoam. Nutr. 56 (2006) 101-109.

[8] Araújo P.S.R., Minami K., Acerola, Fundação Cargill, Campinas, SP, Brazil, 1994, 81 p.

[9] Netto A.G., Ardito E.F.G., Garcia E.E.C., Bleinroth E.W., Freire F.C.O., Menezes J.B., Bordin M.R., Sobrinho R.B., Alves R.E., Acerola para exportação: procedimentos de colheita e pós-colheita, EMBRAPA - SPI, Sér. Publ. Téc. Frutex, Brasília, Brazil,1996.

[10] Neto L.G, Soares J.M., Choudhury M.M., Leal I.M., Oliveira J.R., Soares Filho W.S., Acerola, EMBRAPA-SPI, Coleç. Plantar, Brasília, Brazil, 1999.

[11] Neto L.G., Soares J.M., Acerola para exportação: aspectos técnicos da produção, EMBRAPA, Brasília, Brazil, 1994, 13 p.

[12] Martins C.G.M., Lorenzon M.C.A., Baptista J.L., Efficiency of pollination types in acerola, Caatinga (Mossoró-RN) 12 (1999) 55-59.

[13] Johnson P.D., Acerola (Malpighia glabra L., M. punicifolia L., M. emarginata D.C.): agriculture, production and nutrition, World Rev. Nutr. Diet. 91 (2003) 67-75.

[14] Cavalcante I.H.L., Beckmann M.Z., Martins A.B.G. , Campos M.C.C., Preliminary selection of acerola genotypes in Brazil, Fruits 62 (2007) 27-34.

[15] Melo N.F., Okasaki W.Y., Leite C.B., Fári M., Establishment of in-vitro culture of Barbados cherry (Malpighia emarginata D.C.), Ciênc. Agrotec. (Lavras) 23 (1999) 102-107.

[16] Boulanger R., Crouzet J., Identification of the aroma components of acerola (Malpiphia glabra L.): free and bound flavour compounds, Food Chem. 74 (2001) 209-216.

[17] Motohashi N., Wakabayashi H., Kurihara T., Fukushima H., Yamada T., Kawase M., Sohara Y., Tani S., Shirataki Y., Sakagami H., Satoh K., Nakashima H., Molnár A., Spengler G., Gyémánt N., Ugocsai K., Molnár J., Biological activity of barbados cherry (acerola fruits, fruit of Malpighia emarginata D.C.) extracts and fractions, Phytother. Res. 18 (2004) 212-223.

[18] De Rosso V.V., Mercadante A.Z., Carotenoid composition of two Brazilian genotypes of acerola (Malpighia punicifolia L.) from two harvests, Food Res. Int. 38 (8-9) (2005) 1073-1077.

[19] Freitas C.A.S., Maia G.A, Costa J.M.C., Figueiredo R.W., Sousa, P.H.M., Acerola: produção, composição, aspectos nutricionais e produtos, Rev. Bras. Agrociênc. (Pelotas) 12 (2006) 395-400.

[20] Caceres A., Plants used in Guatemala for the treatment of dermatophytic infections. 2. Evaluation of antifungal activity of seven American plants, J. Ehtnopharmacol. 40 (1993) 3.

[21] Hwang J., Hodis H.N., Sevanian A., Soy and alfalfa extracts become potent low-density lipoprotein antioxidants in the presence of acerola cherry extracts, J. Agric. Food Chem. 49 (2002) 308-314.

[22] Byrne M., New food products in around the world, Food Eng. Int. April (1993) 46-54.

[23] Lee S.K., Kader A.A., Preharvest and postharvest factors influencing vitamin $\mathrm{C}$ content of horticultural crops, Postharvest Biol. Technol. 20 (2000) 207-220. 
[24] Naidu K.A., Vitamin C in human health and disease is still a mystery? An overview, Nutr. J. 2 (2003) 7-16.

[25] Monsoor M.A., Proctor. A., Preparation and functional properties of soy hull pectin, J. Am. Oil Chem. Soc. 78 (2001) 709-713.

[26] Alkorta I., Garbisu C., Llama M.J., Serra J.L., Immobilization of pectin lyase from Penicillium italicum by covalent binding to nylon, Enzym. Microb. Technol. 18 (1996) 141-146.

[27] Serra J.L. Alkorta I., Llama M.J., Alaña A., Aplicación industrial de los enzimas pécticos. Producción, purificación, inmovilización y algunas propiedades de la pectina liasa de Penicillium italicum, Aliment. Equipos Tecnol. 8 (1982) 127-133.

[28] Kashyap D.R., Vohra P.K., Chopra S., Tewari R., Applications of pectinases in the commercial sector: a review, Bioresour. Technol. 77 (2001) 215-227.

[29] Dinella C., Stagni A., Lanzarini G., Pectolytic enzymes co-immobilization on $\gamma$-alumina spheres via organophosphate compounds, Process. Biochem. 32 (1997) 715-722.

[30] Giovane A., Quagliolo L., Servillo L., Balestrieri C., Laratta B., Loiudice R., Castaldo D., Purification and characterization of three isozymes of pectinmethylesterase from tomato fruit, J. Food Biochem. 17 (1994) 339-349.

[31] Versteeg C., Rombouts K.M., Spaansen C.H., Pilnik W., Thermostability and orange juice cloud destabilizing properties of multiple pectinesterases from orange, J. Food Sci. 45 (1980) 969-971.

[32] Wegrzyn T.F., MacRae E.A., Pectinesterase, polygacturonase, and $\beta$-galactosidades during softening of ethylene-treated kiwi fruit, HortiScience 27 (1992) 900-902.

[33] Alonso J., Howell N., Canet W., Purification and characterization of two pectinmethylesterase from persimmon (Diospyros kaki), J. Sci. Food Agric.75 (1997) 352-358.

[34] Assis S.A. de, Lima D.C., Faria Oliveira O.M.M., Acerola's pectin methylesterase: studies of heat inactivation. Food Chem. 71 (2000) 465-467.

[35] Assis S.A. de, Ferreira B.S., Fernandes P., Guaglianoni D.G., Cabral J.M.S., Faria Oliveira O.M.M., Gelatin-immobilized pectinmethylesterase for production of low methoxyl pectin, Food Chem. 86 (2004) 333-337.
[36] Bors W., Heller W., Michael C., Saran M., Flavonoids as antioxidants: determination of radical scavenging efficiencies, Methods Enzymol. 186 (1990) 343-355.

[37] Clifford M.N., Understanding the biological effects of dietary complex phenols and tannins and their implications for the consumer's health and well-being, Eur. Proj. FAIR-CT95-065, Eur. Community Program. Res., Technol. Dev. Demonstr. Field Agric. Fish., 1995.

[38] Hertog M.G.L., Feskens E.J.M., Hollman P.C.H., Katan M. B., Kromhout D., Dietary antioxidant flavonoids and risk of coronary heart disease: the zutphen elderly study, Lancet 342 (1993) 1007-1011.

[39] Moure A., Cruz M. J., Franco D., Domínguez J.M., Sineiro J., Nunez M.J., Parajo J.C., Natural antioxidants from residual sources, Food Chem. 72 (2001) 145-171.

[40] Fitting O.K., Miller C.D., The stability of ascorbic acid in frozen and bottled acerola juice alone and combined with other fruit juices, Food Res. 25 (1960) 203-210.

[41] Cavalcante M.L., Rodriguez-Amaya D.B., Carotenoid composition of the tropical Eugenia uniflora and Malphigia glabra, Food Sci. Hum. Nutr. 20 (1992) 643-650.

[42] Cruz V.D., D'Arce L.P.G., Castilho V.M., Lima V.A., Cruz R., Godinho P.H., Variações no teor de ácido ascórbico de acerolas ( $M$. glabra L.) em função do estágio de maturação e temperatura de estocagem, Arq. Biol. Tecnol. (Curitiba) 38 (1995) 331-337.

[43] Chan H.T., Yamamoto H.Y., Kinetics of anthocyanin decomposition in acerola juice, ASEAN Food J. 9 (1994) 132-135.

[44] Ciolino L.A., Determination and classification of added caramel color and adultered acerola juice formulations, J. Agric. Food Chem. 46 (1998) 1746-1753.

[45] Vendramini A.L., Trugo L.C., Chemical composition of acerola fruit (Malpighia punicifolia L.) at three stages of maturity, Food Chem. 71 (2000) 195-198.

[46] Musser R.S., Acerola no Brasil: produção e mercado, in: Simp. Bras. sobre acerola, UFPE Anais, Recife, Brazil, 1995, p. 4-6. 


\section{Acerola: importancia, condiciones de cultivo, producción y aspectos bioquímicos.}

Resumen - Origen e importancia. La acerola o Malpighia emarginata D.C. proviene de las islas del Caribe, de Centroamérica y de las Amazonas. Esta planta se introdujo recientemente en zonas subtropicales (Asia, India, Sudamérica). La vitamina C producida por la acerola se absorbe mejor por el organismo humano que el ácido ascórbico sintético. La exportación de frutos de acerola es una fuente de ingresos potenciales para las explotaciones agrícolas. En Brasil, el cultivo industrial de esta planta es completamente reciente. Condiciones climáticas. La acerola es una planta rústica que puede resistir a las temperaturas que se aproximan a los $0{ }^{\circ} \mathrm{C}$, pero que se adapta bien a las temperaturas próximas a los $26{ }^{\circ} \mathrm{C}$ y con precipitaciones entre $(1200$ y 1600) $\mathrm{mm}$ anuales. Características del fruto. El fruto de $M$. emarginata es una drupa cuya forma puede ser entre redonda y cónica. Una vez maduro, puede ser rojo, púrpura o amarillo. Su peso varía de (3 y 16) g. Maduración. El metabolismo de la acerola es rápido al igual que su maduración. Si este fruto se comercializa en condiciones ambientales, su transporte debe ser rápido, o tal vez haya que emplear contenedores frigoríficos con el fin de retrasar parcialmente su respiración y su metabolismo. Producción y productividad. La floración y la producción intervienen típicamente por ciclos vinculados con la lluvia. Normalmente estos acontecimientos se llevan a cabo en ciclos de 25 días, hasta ocho veces al año. La planta puede propagarse mediante esqueje, injerto o siembra. Cosecha. Los frutos para la venta en mercados deben cosecharse en su momento de maduración óptima. Para puestas en marcha alejadas, deben envasarse en cajas amontonadas a una altura reducida, el transporte debe llevarse a cabo en camiones frigoríficos y en condiciones húmedas relativamente elevadas. Constituyentes bioquímicos. El fruto de acerola es la fuente natural más importante de vitamina C [(1000 a 4500) $\mathrm{mg} \cdot 100^{-1} \mathrm{~g}$ de pulpa], sin embargo también es rico en pectina y encimas pectolíticas, carotenoides, fibras vegetales, vitamina B, tiamina, riboflavina, niacina, proteínas y sales minerales. Asimismo posee propiedades fungicidas activas. Productos y mercado. La acerola se emplea en la producción de zumo, bebidas sin alcohol, golosinas y licores. Los Estados Unidos y Europa son grandes mercados potenciales. En Europa los extractos de acerola sirven para enriquecer los zumos de pera o de manzana. En los Estados Unidos se emplean en industrias farmacéuticas. Conclusiones. La demanda de acerola ha aumentado considerablemente a lo largo de estos últimos años a razón del interés de la vitamina $\mathrm{C}$ para la salud humana, añadido al empleo del ácido ascórbico como antioxidante en alimentación y en nutrición. El fruto de acerola contiene otros constituyentes interesantes, susceptibles de llevar a un crecimiento posterior de su producción y a su comercio mundial.

Brasil / Malpighia emarginata / frutas / composición aproximada / usos / mercados mundiales 